\title{
Administrators' Finance Utilization as Predictor of Intramural Sports Development in Government Secondary Schools in Delta Central Senatorial District
}

\author{
Edenedo, Edirin Edward \\ Physical \& Health Education Department, Delta State University, Abraka \\ Email: edenedoedward@yahoo.com \\ Akarah, Emmanuel \\ Physical \& Health Education Department, Delta State University, Abraka \\ Email: dedonspino@yahoo.co.uk \\ Tayire, Favour Okagbare
}

Physical \& Health Education Department, Delta State University, Abraka

\author{
Doi:10.5901/ajis.2014.v3n6p145
}

\begin{abstract}
Intramural sports in the Government secondary schools in Delta Central Senatorial District have been on the decline. Athletes with outstanding performance oftentimes are not rewarded, facilities and equipment are either inadequate or not provided perhaps, because the school sports administrators do not take into cognizance the importance of utilizing financial resources to cater for specific needs of the intramural sports programme. A sample size of 541 respondents purposively sampled from a target population of 1081 persons was used for the study. The study sought to ascertain if administrators' finance utilization would predict intramural sports development in Government Secondary Schools in Delta Central Senatorial District. A self structured questionnaire rated on a four point Likert type scale was used to elicit responses from the respondents. A reliability index of 0.72 was established using the Pearson's Product Moment Correlation Coefficient while the data was analyzed using Linear Regression Statistics at 0.05 level of significance. The analyzed data revealed that administrators' finance utilization significantly predicts intramural sports development in Government Secondary Schools in Delta Central Senatorial district; $F$ $(2,535)=49.95, D F=1, P<.05, r=.29$. The study recommended that school sports administrators should be trained in the area of fiscal management.
\end{abstract}

Keywords: Administrator, Finance utilization, Sports development, Facilities and equipment

\section{Introduction}

The specific function of an administrator in every organizational setting lies in the efficient and effective utilization of human and material resources within an integrated setting so that the stipulated objectives can be achieved within the set time (Nakpodia, 2006). It becomes note worthy to mention that, for resources to be effectively utilized, there must be somebody at the administrative helm who will ensure that the needed human and material resources are put into proper usage by ascertaining that such resources are adequately obtained from predetermined sources through planning and budgeting and, when these resources are obtained, they should be expended for the specified purposes. Udom (1999) posited that the administrator's function lies in the effective utilization of an organization's resources to achieve the organization's goals and objectives through adequate planning, organizing, directing and controlling. The statement above depicts a situation where the absence of resources could mar the achievement of organizational goals.

Igbanugo (2003) posited that finance is critical to the success and effective utilization of the resources in any organization as its availability necessitates the purchase of every material required for the attainment of the organization's goals. She further defined sports as institutionalized competitive activities that involve physical exertion or the use of complex physical skills. It is often undertaken by individuals who are motivated by intrinsic satisfaction with the activity itself or by external reward or a combination of both. Sports, according to Babalola and Oyeniyi (2003) is a social agent that brings people of different ages and religious background together whether as producer or consumer with the intent that leisure time is judiciously used. Sports are regarded as integral parts of the total educational process that contribute 
to the intellectual growth and human development of youths. Its contribution to the social, physical, emotional, and cognitive development of youths cannot be over-emphasized. There would be no gainsaying that the attainment of these benefits may have prompted the establishment of various intramural and interscholastic secondary school sports competitions across Nigeria by the National Sports Commission.

Intramural sports need adequate financing as they are comprehensive programmes of sports and recreational activities carried out within the institution. Attaining predetermined sports objectives in secondary school students lie in the ability of the sports administrators to judiciously utilize financial resources. Omolawon and Adisa (2009) espoused that as lofty and beneficial as the idea of intramural sports is, the objectives are threatened with issues bothering on proper utilization of financial resources. It would only be proper that an athlete who excels in an inter-house athletic competition should be given some form of reward or remuneration for a job well done just as much as it would also be proper to reward volunteers who contributed their quota in terms of efforts and support towards the successful hosting of sports meets.

Omolawon (2003) sees development as a discernable qualitative, positive and enduring transformation of people, infrastructure, and superstructure. Development involves freedom, access to information and significant improvement of a body or event over previous status. In the sports context, development would imply the discovery of sports prodigies who are grafted into national sports bodies, frequent organization of sports at specified times, proper remuneration scheme amongst others. Omalawon and Adisa (2009) asserted that for the goals and objectives of sports in secondary schools to be achieved which would invariably culminate to sports development, the place of judicious finance utilization by the administrators would be of paramount importance. They further opined that one of the ultimate responsibilities of the administrator in attaining stipulated goals in sports, is to ensure proper organizational and administrative control of financial resources at the least possible cost whilst maximizing its profits through the mechanism of proper planning and budgeting.

Idowu (2011) citing Lawal (1993) asserted that administrators who plan well, utilize financial resources more than administrators who do not plan. He defined planning as management skills that focus on stipulating means for the attainment of specified objectives in sports while budgeting according to Cole (2000) is a statement usually expressed in financial terms, of the desired performance of any organization in the pursuit of its objectives. This study therefore attempts to ascertain if administrators' finance utilization would predict sports development in the Government secondary schools in Delta Central Senatorial District especially against the backdrop of the fact that athletes would expect to be motivated to participate in sports competitions in order to attain outstanding performances in sports events. In like manner, government would not want to invest more financial resources if they do not notice judicious usage of previously allocated resources in the provision of adequate facilities and equipment.

\section{Statement of the Problem}

Secondary school sports no doubt provide the appropriate environment to get and groom budding athletes. Aibueku (2003) stated that purposeful and sustainable sports growth and development in Nigeria would have to be anchored on efficient and grassroots sports development. This is because, the schools are supposed to be the reservoir of vibrant youths with exuberant energy drives for physical activity. It would apparently be difficult to actualize the "catch them young" approach in the isolation of school sports especially at the lower levels of the educational system. At the secondary school level, the objectives of the National Sports Development Policy (2000) is to promote an awareness of the need for general fitness, encourage mass participation in physical activities, provide personnel for training in physical activities and sports, adequately provide and maintain facilities and equipment as well as fund and organize sporting activities. Omolawon and Adisa (2009) noted that organization of intramural sports programme in government secondary schools has suffered a lot of setbacks due to problems associated with improper planning and budgeting of financial resources at the secondary schools.

\section{Hypothesis}

The following research hypothesis was formulated to guide this study.

Administrators' finance utilization will not significantly be a predictor of intramural sports programme in government secondary schools in Delta Central Senatorial District. 


\section{Methodology}

The descriptive survey research design was adopted for the study. This design was suitable because it deals with the collection and analysis of data for the purpose of describing existing conditions, prevailing practices, attitude as well as on going processes as they exist in their natural settings (Egbule and Okobia 1998). The population for the study comprised of one thousand and eighty two intramural sports administrators in eight local government areas (Uvwie, Udu, Ughelli North, Ughelii South, Okpe, Sapele, Ethiope East, Ethiope West) of Delta Central Senatorial District from which a sample size of 541 which accounted for $50 \%$ of the entire population was purposively sampled. A self developed and structured questionnaire validated by four experts each in sports administration at the Delta State University, Abraka and the University of Benin was used for data collection. The instrument's reliability was established through a test retest method on thirty respondents in areas other than the ones used for the study and calculated with the Pearson's product Moment Correlation Coefficient which established the reliability coefficient index at 0.72 . The data generated from the respondents that constitute the sample for the study was analyzed using linear regression statistics at 0.05 alpha level of significance.

\section{Hypothesis Testing}

Administrators' finance utilization will not significantly be a predictor of intramural sports development in Government Secondary Schools in Delta Central Senatorial District.

\begin{tabular}{|c|c|c|c|c|}
\hline Model & $\mathrm{R}$ & $\mathrm{R}^{2}$ & $\mathrm{R}^{2}$ Adjusted & Std. Error the Estimate \\
\hline 2 & .291 & .085 & .083 & 1.33982 \\
\hline \multirow{4}{*}{$\mathrm{df}$} & \multicolumn{3}{|c|}{ Anova } \\
& 1 & Ss & $\mathrm{ms}$ & $\mathrm{F}$ \\
& 535 & 964.99 & 89.59 & $49.95^{* *}$ \\
& Unstandardized coefficient & \multicolumn{2}{|c|}{ Standardized } & $\mathrm{t}$ \\
\hline \multirow{3}{*}{ Constant Finance } & B SEB & \multicolumn{2}{|c|}{ Beta } & 23.47 \\
& 16.39 .70 & \multicolumn{2}{|c|}{-29} & $-7.07^{* *}$ \\
\hline
\end{tabular}

The table above contains correlation, regression coefficients and Beta standardize regression coefficient of administrators' finance utilization and intramural sports development in government secondary schools in Delta Central Senatorial District. The result indicated that there was a significant correlation between administrators' finance utilization and intramural sports development in government secondary schools in Delta Central Senatorial District $F(2,535)=$ 49.95, $\mathrm{df}=1, \mathrm{P}<.05, \mathrm{r}=.29$ which accounted for $8 \%$ variance in intramural sports development. Therefore the hypothesis was rejected. This implies that administrators' finance utilization is a predictor of intramural sports development in Government Secondary Schools in Delta Central Senatorial District.

\section{Discussion}

From the findings obtained in the table, the study has shown that administrators' finance utilization is a predictor of intramural sports development in Government secondary schools in Delta Central Senatorial District. Administrators' finance utilization depicts a situation where administrators are able to utilize finance to purchase every material required for the attainment of organizational goals as espoused by Igbanugo (2003). Omolawon and Adisa (2009) support the findings of the study when they noted that, as lofty and beneficial as the idea of intramural sports may be, the objectives are threatened with issues bordering on proper utilization of financial resources and that; the place of judicious financial utilization by administrators would be of paramount importance if sports development goals and objectives have to be attained in secondary schools.

\section{Conclusion}

The findings of the study have revealed that administrators' finance utilization would predict intramural sports development in Government Secondary Schools in Delta Central Senatorial District. There is therefore great need for administrators of sports programmes to be well grounded with the skills and knowledge of proper planning and utilization 
of financial resources that will enhance and ensure sports development.

\section{Recommendation}

The study thus recommends that the awareness level of secondary school sports administrators should be heightened by being trained in the area of fiscal management and finance utilization if sports need to be developed to the extent that the secondary schools would be avenues for identifying and grooming budding sportsmen that would represent Nigeria as a nation at sports meets.

\section{References}

Abdul, A.A. (2003). Determinants of effective administration of intramural sports programme in Lagos state secondary school. Ibadan: Stirlen - Horden Publisher Nigeria Limited.

Aibueku, S. O. (2003). Analysis of the implementation of sports development policy in grassroots institutions in Edo State. Unpublished Ph.D Dissertation, University of Benin.

Asagba, B.O., Odewuni, G.I. and Oladipo, S.E. (2009). Anxiety Obsession and health concern of sports administration as correlates of effective sports management in Ekiti and Osun States of Nigeria. Nigeria Journal of Sports Management Vol. 3. Pp 33.

Cole, G.A. (2000). Measurement theory and practice (5th $e d)$ London: Ashford Press Compney.

Egbule, J.F. and Okobia (1998). Research Method in Education for Colleges and University. Agbor: KAMENSUO educational publishers. Idou, K. (2011). Management of Fitness and health centers. Ibadan: Olu - Akin Publishers.

Igbanugo, V.C. (2003). Science and Reseach: The Ultimate means developing sprts excellence. Ibadan: Stirlen - Horden Publisher Nigeria.

Nakpodia, A. (2006). Educational administration. Meaning, concept and theories of educational administration. Effurun: Jonokase

Omolawon, K.O. (2003). Fiscal Management, Source Funding and Utilization as Bases for Effective Administration of Physical Education and Sports Programme West African Journal of Physical and Health education, 7, 125 - 130.

Omolawon, K.O. and Adisa, O. (2009). Budget planning, allocation and implementation as indices for intramural sports programme among Osun State Owned Tertiary Institution. Nigeria Journal of Sports Management. Vol. 3 Pp 24. 